\title{
Atheism in the American Animal Rights Movement: An Invisible Majority
}

\author{
COREY LEE WRENN
}

School of Social Policy, Sociology and Social Research

Cornwallis North East

University of Kent

Canterbury, Kent

Email:c.l.wrenn@kent.ac.uk

\begin{abstract}
Previous research has alluded to the predominance of atheism in participant pools of the Nonhuman Animal rights movement (Galvin and Herzog 1992; Guither 1998), as well as the correlation between atheism and support for anti-speciesism (Gabriel et al. 2012; The Humane League 2014), but no study to date has independently examined this demographic. This article presents a profile of 210 atheists and agnostics, derived from a larger survey of 287 American vegans conducted in early 2017. Results demonstrate that atheists constitute one of the movement's largest demographics, and that atheist and agnostic vegans are more likely to adopt veganism out of concern for other animals. While these vegans did not register a higher level of social movement participation than religious vegans, they were more intersectionally oriented and more likely to politically identify with the far left. Given the Nonhuman Animal rights movement's overall failure to target atheists, these findings suggest a strategic oversight in overlooking the movement's potentially most receptive demographic.
\end{abstract}

\section{KEYWORDS}

Animal rights; atheism; secularism; social movements; veganism

\section{INTRODUCTION}

The relationship between atheism and anti-speciesism has shown promise in previous research, but it has only been mentioned parenthetically in studies that otherwise prioritise race, class, gender, social values, political attitudes 


\section{COREY LEE WRENN}

and other demographic profiles of Nonhuman Animal rights activists, vegans and vegetarians. This body of research supports the claim that fundamentalist religious views are correlated with a resistance to anti-speciesist values (Dhont and Hodson 2014; Monteiro 2012; Peek et al. 1997), while atheism and agnosticism are correlated with support for Nonhuman Animal rights (Gabriel et al. 2012; The Humane League 2014). Indeed, while comprising just one to nine per cent of the general American population (Williamson and Yancey 2013), ${ }^{1}$ atheists and agnostics predominate as the largest categories of religious affiliations in demographic surveys of the Nonhuman Animal rights movement (Galvin and Herzog 1992; Guither 1998).

Perhaps owing to the movement's historical association with religious institutions and tactics, vegan atheism (a term I use as shorthand for atheistic anti-speciesist activism) has remained almost completely unstudied by social movement scholars, policymakers and nonprofit organisations. In the eighteenth and nineteenth centuries, the western Nonhuman Animal rights movement positioned violence against other animals as evidence of moral depravity and prescribed Christian values as a cure for this social ailment (Beers 2006; Davis 2016; Ritvo 1989). Under European colonialism and, later, American imperialism, ruling parties sought to justify their global civilisation agenda by pointing to the 'barbarities' of colonial subjects with regard to their treatment of other animals. Domestically, Nonhuman Animal welfare was also politicised in the racial suppression of Black, Latinx and other communities of colour. Progressive-era activists in the United States essentially believed that 'beastly' humans could be domesticated for assimilation into 'civilised' society, such that their relationships with other animals became allegorical. The early movement was highly anthropocentric, concerned as it was with the wellbeing of humans rather than the actual wellbeing of other animals (Boddice 2008). Organisations such as the Women's Christian Temperance Movement, for instance, funded targeted humane campaigns that were designed to cultivate and Christianise socially marginalised groups via their treatment of Nonhuman Animals.

The religious frame was a dominant one in first wave Nonhuman Animal rights, but it would be challenged by new ideologies of modernity (Maurer 2002). Humanistic thought in the philosophical tradition, for instance, advanced the notion of individualism to the potential benefit of Nonhuman Animals (Preece 2006), although it certainly centred humans, as its name suggests (Singer [1975] 2002). Nineteenth-century humanitarians, many of whom were critical of organised religion, were also major advocates of vegetarianism and rights for other animals (Beers 2006). Likewise, the rise of science as an institution as well as the window of opportunity provided by Darwin's evolutionary theory sparked a renewed interest in secular, rationalist and evidence-based anti-speciesism in the late-nineteenth and early-twentieth

1. Estimates vary based on variations in study design and sample populations. 
centuries, claims-making that had already been brewing in philosophical thought of the Enlightenment era.

As the movement entered its second wave in the late-twentieth century, it seemed to exhibit an element of identity crisis. Especially in the 1980s and 1990s, it was marked by a strong anti-science position, specifically in its single-issue focus on resisting vivisection (Jasper and Nelkin 1992). Yet, modern anti-speciesism was also informed by rational argument and scientific evidence in support of non-human sentience, animal agriculture's relationship with climate change, and the deleterious impact of animal protein on the human body (Freeman 2014; Iacobbo and Iacobbo 2006; Maurer 2002; Munro 2005). The evangelicals and missionaries that had once dominated its rank-and-file had been replaced by civil rights activists of a secular persuasion. However, claims-making continued to accommodate religious frames even though most activists were not religious themselves.

Historian Rod Preece (2006) rightly observes that there is 'no orthodoxy in the history of animal ethics' (2). Arguably as a result of this somewhat muddled framework, the movement's atheism and associated preferences for secular and scientific claims-making remains something of an unknown. This study will present a history of atheism, and, to a lesser extent, secularism in the American Nonhuman Animal rights movement to ground the relevance of the demographic analyses. It is not designed, however, to test organisational justifications for continued atheist invisibility. Instead, it aims to initiate an inquiry into the under-researched vegan atheist demographic with an examination of findings derived from my 2017 online survey of American vegan respondents. Veganism and anti-speciesism frequently overlap, but this study cannot assume that all vegan respondents were necessarily involved with the vegan movement or the Nonhuman Animal rights movement. However, research (including this study) supports the assumption that the majority of vegans are, in fact, politically engaged (Wrenn 2017a), most frequently in the field of Nonhuman Animal rights (McDonald 2000). For this reason, this study contextualises results within the politics of the western Nonhuman Animal rights movement.

Crucially, I argue that the American variant of the movement is not only characterised by a white, middle-class and female majority, but is also patently atheistic. I further argue that, based on the high levels of pro-social behaviour that this atheist demographic exhibits, the movement could benefit from more explicitly and strategically engaging the atheist community. However, doing so would require a delicate negotiation of these potential benefits with the significant stigma attached to atheism. It could be, therefore, that the movement may not wish to incur such additional costs, given the stigma already attached to Nonhuman Animal rights activists and veganism, more broadly. 


\section{COREY LEE WRENN}

\section{LITERATURE REVIEW}

\section{Negotiating religion and science in the first wave of anti-speciesism}

Veganism is a political and dietary practice that entails the eschewing of animal products. Dietary vegans concern themselves only with animal-based foods, but political vegans may also refrain from consuming animal-based clothes, entertainment or labour. Veganism as a political concept originated in the nineteenth century, formalising with the establishment of the United Kingdom's Vegan Society in 1944 (Wrenn 2019). In eastern cultures, however, vegan lifestyles have been relatively familiar for thousands of years. Prior to the expansion of western markets, plant-based consumption was normative for most, and these material practices were reinforced by Buddhism, Jainism, Hinduism and other religious doctrines that encouraged respect for Nonhuman Animals (Kemmerer 2012).

In the west, where material conditions allowed for the resource-intensive rearing of 'livestock', cultural norms developed that were, by contrast, heavily speciesist (Nibert 2013). Systematic violence against Nonhuman Animals grew in both scale and severity under the industrial revolution, with non-human bodies and labour providing the raw materials for capitalist growth. The gratuitous oppression of Nonhuman Animals, often linked with violence against vulnerable human groups, would encourage many to question the ethics of domination. Indeed, the callousness of capitalist enterprise in the early industrial period ran contrary to hegemonic Christian teachings of love, kindness, patience and piety. Beginning in the seventeenth century, debates surrounding Nonhuman Animal ethics were couched in religious frameworks and considered the possibility of non-human souls. However, some Enlightenment thinkers began to regard the importance of sentience, rationality and natural rights as relevant to humanity's obligation to other animals (Maehle 2012), just as philosophy of the era debated the social role of religion itself. In this section, I explore the tension between religion and science in the anti-speciesist repertoire. Although this dualism does not focus on atheism per se, American atheists tend to be motivated by scientific and empirical epistemologies (Williamson and Yancey 2013); consequently, these themes likely influence the predominance of atheism among today's ranks.

Religious revivalism of the late-eighteenth and early-nineteenth century positioned itself as a form of moral resistance to the sweeping social changes that appeared poised to despoil humanity. Vegetarianism was employed by early evangelists, usually as a means of practising temperance and achieving spiritual purity (Shprintzen 2015). Christian minister William Cowherd, for instance, is generally credited as the founder of organised vegetarianism in the west. At times, this spiritual vegetarianism would be blended with humane efforts. Vegetarianism and concern for other animals was not simply a demonstration of personal faith, but a means of bettering society. By way of 
an example, the famous Alcott family in America briefly realised their utopian vision by blending their romanticism with anti-slavery abolitionism, plantbased diets and simple living in their Fruitlands communal experiment in New England (Francis 2010). Likewise, in the early nineteenth century, temperance activist Asenath Nicholson operated a vegetarian boardinghouse in the slums of New York City, and was also active in resisting American slavery and organising assistance to the diseased and starving in Ireland's potato famine (Murphy 2015).

The late-nineteenth century saw a spike in humane claims-making corresponding with the upheaval wreaked by industrialisation and modernisation that drew concerns about the moral wellbeing of the populace, particularly its children. The Nonhuman Animal rights movement had gathered momentum at this time, and eagerly capitalised on this political opportunity by promoting spiritually oriented literature - a campaign Janet Davis (2016) describes as a 'gospel of kindness' (4) in her book of the same name. Another consequence of the industrial age was the growth of science as an institutionalised discipline and its influence on culture and knowledge production. Welfare activists and vegetarians alike began to incorporate scientific frameworks into their outreach efforts. Some activists, however, such as anti-vivisectionist Frances Power Cobbe, remained ardently distrustful, having been made vigilant by many years battling the 'smooth cool men of science' (Kean 1995, 16). Scientists had successfully wielded their newfound cultural power to justify and legitimise all variety of cruelties against the marginalised, both human and nonhuman, and did so in the name of scientific inquiry and societal improvement (Ryder 1989).

The institution of science upturned Victorian mores regarding privacy, etiquette and morality (Ferguson 1998). Whereas welfare activists had been encouraging kindness toward other animals for the benefit of society, scientists were encouraging their objectification for the same reason. To the movement's horror, scientists' newfound social power increased the credibility of their speciesist claims. The elevation of scientists also challenged religious appeals for social work as social Darwinism excused the suffering of society's most vulnerable as a consequence of natural selection. Furthermore, the scientific institution challenged traditional class structures given that many emerging medical practitioners hailed from the rising middle classes. For these reasons, science remained alien or antagonistic to the aristocratic and relatively conservative elites who led the first wave of western anti-speciesism. An occupation in the sciences offered a rare opportunity for social mobility, disrupting the cultural association of violence against animals (farming, tanning, slaughtering, butchering and petty cruelty) with the lower classes (Ryder 1989). It was now the powerful and revered who were conducting violence against Nonhuman Animals; as a result, many activists took to discrediting science itself in hopes of curtailing its hegemonic rise. 


\section{COREY LEE WRENN}

Other activists opted to capitalise on the cultural enthralment with science. By the mid-nineteenth century, religious frames continued to dominate but health frames (often related to religious ideals of aestheticism and purity) also grew in popularity, as evidenced in the celebrity of American dietary reformers, the Reverend Sylvester Graham and John Harvey Kellogg M.D., both of whom built careers on their variation of a 'natural' diet and 'clean living' lifestyle. As the legitimacy of science grew, activists were eager to employ a scientific framework to lend credibility to their anti-speciesist claims. The Progressive Era humanitarian movement, which was often characterised by an anti-speciesist element, commonly drew on Darwinian theory as evidence for their argument that humans and other animals were and are interconnected in a universal kinship. Like Kellogg, they, too, leaned on scientific research in support of substitutes for meat, leather and other animal products (Jarvis 2009).

Activists could thus increasingly draw on science to demonstrate the superiority of their position. In an age in which illness and premature death were commonplace, this approach was a potent one. Where vegetarianism had once been prescribed for spiritual health, now it was also prescribed for physical wellbeing. This changing framework was a source of disagreement, to be sure, as some activists criticised others for overreaching their claims and insisted on their ability to demonstrate scientific credibility. Playwright and vegetarian icon George Bernard Shaw, for instance, maintained the importance of rationalist argumentation throughout his career, disparaging early vegetarian claims that plant-based living was the cure to all ailments (Holroyd 1997). Some activists at the turn of the twentieth century were also hostile to vaccination science, not simply because it necessitated vivisection, but also because of the high likelihood that vaccinations would be used in lieu of the structural changes needed to alleviate the oppressive, insanitary living conditions endured by the poor (Jarvis 2009). The role of rationality also kick-started The Vegan Society in the early 1940s, with early editorials espousing the importance of backing vegan claims with evidence and advising activists to distance themselves from the spirituality and astrology that surfaced regularly in competing vegetarian literature (James 1948). Indeed, the persistence of secular anti-speciesist claims-making is credited for easing the movement's first wave into a modern era in which the old religious, moral reform approach had become antiquated ( $\mathrm{Li} 2012$ ).

If this rigorousness in accountability had benefited the movement, perhaps it would be commendable, yet there remain other limitations to this shift in claims-making that should be addressed. First, Darwin's revelations did not create some new impetus for Nonhuman Animal ethics among the public and, for that matter, his idea that humans shared kinship with other animals had already been well examined by philosophers (see Boddice 2008). The movement's effort to incorporate rationality, in other words, was not a golden ticket to antispeciesism. Even atheist humanitarian Henry Salt supported anthropocentrism, 
sanctioning the use of other animals as long as it was perceived to be humane. For him, the abuse of Nonhuman Animals did not necessarily derive from religion, specifically, but rather from the failings of human culture. Furthermore, Darwin's evolutionary work encouraged a great surge in vivisection as researchers eagerly pursued greater scientific understanding. As Preece (2006) argues, Christianity's advancement of anti-speciesism may have been complex and spotty, but perhaps it was more favourable than its alternatives, at least when compared to the scientific approach.

Secular reasoning and atheistic tendencies in second wave anti-speciesism

Religious and philosophical studies have each investigated animal ethics extensively, but generally stop short of atheist thought. Kim Socha's (2014) Animal Liberation and Atheism is the only monograph as yet to offer an explicitly atheist critique of institutionalised religions and their speciesist positioning of Nonhuman Animals. Otherwise, very little second-wave commentary exists in published form. Nonhuman Animal ethicist Bernard Rollin (2009) offers a brief commentary in which he concludes that 'religious belief is neither necessary nor sufficient for assuring ethical behavior' (347), but his dismissal of religiosity is not a common one. Michael Fox (1983) also touched on the movement's frustration with religious and economic counter claims-making, which frequently pitted anti-speciesism as communistic, atheist and unpatriotic, in an editorial for the short-lived International Journal for the Study of Animal Problems. Fox was critical of organised religion's attempt to enforce 'simplistic and moralizing conformity' (ibid., 172), but he was by no means attempting to defend atheism. Rather, his argument suggests that the Nonhuman Animal rights movement was wary of atheist stigma and eager to disassociate itself from the stereotypes lobbed by speciesist institutions. Activists, he assured readers, were not atheistic; they were only practising 'thoughtful enquiry into society's religious and political values' (ibid.). Their view of 'god' was one of universal love, not the more common interpretation of patriarchal domination. Furthermore, according to Fox, all 'religious and spiritually enlightened people of the world' (ibid.), be they anti-speciesists or not, are morally obligated to resist amoral atheism as it (re)surfaces in science and technology.

The two titans of twentieth-century vegan philosophy, Peter Singer ([1975] 2002) and Tom Regan (1983), were a bit more forgiving in this regard, both offering secular arguments for Nonhuman Animal rights that might easily appeal to atheists. Regan continued to see promise in a religious argument, however, even producing a documentary in the 1980s on religion's congruence with anti-speciesism. As one biographer writes: 'Regan bucked the trend among secular animal rights philosophers and spoke patiently and persistently to the best angels of religious ethics' (Halteman 2018, 153). Singer, perhaps the leader of this secular trend, has been critical of religion's role in upholding 
speciesism. He identifies the Catholic Church, in particular, as a bane to the advancement of other animals but sees the average practitioner, too, as being 'limited by the basic outlook of their religion' (Singer [1975] 2002, 197). In his subsequent publication, Practical Ethics (1979), he reiterates that: 'our everyday observation of our fellows clearly shows that ethical behavior does not require belief in heaven and hell' (4). For Singer, then, ethics can be rooted in 'benevolence and sympathy for others' (ibid.); elsewhere, he muses that the rise of various institutionalised religions often reflects the speciesism of the human beings who developed them' (Singer and Mason 2006, 253). An atheist himself, Singer stops short of producing an explicitly atheist theory with regard to Nonhuman Animals, relying instead on notions of utilitarianism, pragmatism and effective altruism. ${ }^{2}$

Beyond academic discussions, movement strategists applied expressly secular political logic to anti-speciesist efforts, inspired as they were by the rational model of bureaucratic efficiency (Garner 1998; Stallwood 2014; Ryder 1989). The second wave of the western Nonhuman Animal rights movement reached its crest in the 1980s and 1990s, at least in part due to the success of this rational model. At the same time, however, its commitment to religious framing was partially renewed, as second wavers employed religious formulations as part of a variety of other tailored campaigns. This tactical diversification reflects the movement's professionalisation, specifically, its need to mobilise a variety of resources in order to appeal to the widest possible audience (see Wrenn 2020). Relatively moderate and culturally appropriate repertoires subsequently come to replace radical options in a bid to maximise fund-raising and grant appeal. Commercial interests notwithstanding, contributions to early outreach literature by such heavyweight theorists as Regan and Carol Adams indicate that movement leaders were deeply invested in the 'promise' of religion. Nevertheless, even areligious frames were subject to religious interpretation. In their profile of the movement, sociologists James Jasper and Dorothy Nelkin (1992) refer to the Nonhuman Animal rights campaign as a 'moral crusade' with tactics and goals described in religious terms:

The language of moral crusades is sometimes shrill, self-righteous, and uncompromising, for bedrock principles are non-negotiable. In the strident style of Old Testament prophets, scolding and condemning their society, organizers point to evils that surround them and to catastrophes that will befall society in the absence of reform. (8)

Given the highly rationalised movement structure and the adoption of secular claims-making, it might be a stretch to liken activists for other animals to 'Old

2. Singer has written elsewhere on the topic of atheism and morality, however; see Singer and Hauser (2017). 
Testament prophets', but it is still the case that the denunciation of religiosity in vegan claims-making is relatively uncommon, aside from the work of Singer.

\section{The case for atheism in third wave anti-speciesism}

Most likely a consequence of employing religiosity to appeal to a predominantly religious audience, atheism has not been expressly examined in the predominating movement dialogue today. The severity of atheist stigma in American society (see Williamson and Yancey 2013) is presumably a consideration for the movement's decision-makers, yet the results of this study suggest that the reluctance and thus failure to mobilise atheism effectively may still be a strategic misstep. Although atheists are commonly stereotyped as being vaguely 'immoral' or lacking a value system, research demonstrates that this group often outperforms its religious counterparts on a number of ethical measures including, but not limited to, Nonhuman Animal rights and welfare issues.

Early sociologists such as Émile Durkheim, Max Weber and Karl Marx understood religion as an institution of social cohesion, socialisation and social control. Indeed, they variously point out that religion, as an ideological enforcer, is potent in its ability to structure social relations, creating pathways of least resistance and adding a sense or order and predictability to social life. Thus, to deviate from religion as a key social institution generally entails some level of social innovation. One meta-analysis of atheist and agnostic thoughtprocessing finds an association between analytic thinking and religious disbelief (Pennycook et al. 2016). Psychological research also finds that areligious people are more motivated by compassion and are more generous than their religious counterparts (Saslow et al. 2013). These findings offer some indication as to why atheists may be more likely to become vegan and advocate for other animals, given their propensity for prosocial behaviour and challenging conventions. As psychologist Ken Shapiro (2018) observes: '[t]he way of being of a faithful atheist - awe and wonder, mystery and respect, humility and courage, acceptance of finitude and ultimate aloneness - is consistent with particular attitudes toward and valuation of the ecosphere' (212). For Shapiro, an acknowledgement that the material world is not divinely managed and therefore invincible instils in the atheist a propensity to care for nonhuman life, particularly given the biological existence of empathy in humans.

Although no previous research has quantified the relationship between atheism and veganism, some studies suggest that American Nonhuman Animal rights activists harbour a general suspicion of science (see, for example, Jamison and Lunch 1992). This scepticism is a hangover from first-wave movement framing that encouraged distrust in scientific institutions given both their propensity for systematic violence against other animals and the 
manipulative counter-frames these institutions provide to protect such practices. Nonetheless, this kind of scepticism is indicative of rational, critical thought, not anti-science sentiment per se. Indeed, atheists are some of society's most avid supporters of scientific inquiry but also do not hesitate to employ mindful scepticism, aware that scientific methods and data can be flawed (Williamson and Yancey 2013).

A propensity for critical thinking and comfort with challenging hegemonic institutions are characteristics that may well align atheists with veganism but so, too, is the tendency to empathise and extend moral concern to others. One survey of North American Nonhuman Animal rights protesters suggested that these activists were more likely to subscribe to an 'absolutist ethical ideology', which the researchers defined as an 'orientation characterised by the belief that moral principles are universally applicable' (Galvin and Herzog 1992, 147). Approximately half the participants in this particular study were atheist or agnostics (only 34 per cent claimed religious membership); however, despite this remarkable correlation, the researchers were quick to dismiss the findings, ensuring readers that their results '[did] not mean that there is not a religious component to the involvement of many activists' (145).

\section{Accommodating stigma}

The nexus of veganism and irreligiosity poses a dilemma for anti-speciesist charities. Both veganism and atheism are heavily stigmatised, making the movement's association with either one difficult, much less both. Erving Goffman (1963) noted that individuals burdened with stigmatised identities will often engage in impression management in the hopes of controlling how others will view them and to avoid undue discrimination. Since vegans frequently disrupt communal food rituals in their unwillingness to consume animal products, they might risk alienation from their peers (Bresnahan et al. 2016); thus, vegans may seek to alter their impressions to manage this stigma (Greenebaum 2012). One study, for instance, finds that American vegans frequently subscribe to the notion that speciesism is a collective social problem that requires a collective response. Yet, when pressed in social settings, they manage this belief by falling back on individualistic explanations of their veganism so as to avoid ostracisation (Turner 2019). In both the United States and the United Kingdom, researchers have documented the deeply negative portrayal of vegans in mainstream media (Cole and Morgan 2011; Greenebaum 2016). At the societal level, the relationship between food and national identity in the cultural imagination also puts veganism at a disadvantage. In an animalproduct based economy, plant-based alternatives can be positioned as a threat to national identity, and many vegan products such as falafel, tofu, tempeh and tahini are coded as foreign and, thus, suspiciously unpatriotic (Wright 2015). Concerned as it is with its presentation to the public, the Nonhuman Animal 
rights movement is generally hesitant to openly and consistently embrace veganism as relevant to its anti-speciesist agenda (Wrenn 2018).

As with food culture, religiosity, too, is found to be a key component in the maintenance of cultural membership, with atheists frequently described as unpatriotic and a threat to national identity. Atheists are arguably the most stigmatised group in American society, such that Penny Edgell et al. (2006) report that 'the gap between acceptance of atheists and acceptance of other racial and religious minorities is large and persistent' (see also Edgell et al. 2016). Indeed, their research indicated that American atheists were even more stigmatised than Muslims following the September 11th terrorist attack. An atheist identity thus comes with considerable social costs. One 2008 religious survey found that forty per cent of atheists had recently experienced discrimination based on their areligious identification (Hammer et al. 2012). Atheists are, in fact, so marginalised that their marginalisation is infrequently acknowledged or taken seriously. Psychological research even finds evidence of stress typically associated with minority status, suggesting that atheists are quite conscious of their stigma and the discrimination they face (Brewster et al. 2016).

While vegans are often dismissed as hyper-moral (Minson and Monin 2011; Turner 2019), atheists are more commonly stereotyped as amoral or immoral (Wright and Nichols 2014). Given the connotations of purity associated with many religions, atheists are also likely to be viewed with disgust for occupying a religious 'out-group' (Ritter and Preston, 2011). This creates a certain difficulty for social movements since many are already burdened with the task of advancing a relatively unpopular identity. Social movements must nevertheless grapple with constructing a group identity that is welcoming and encompassing for their rank-and-file, but does not repel audiences. Aidan McGarry and James Jasper (2015) refer to this characteristic negotiation as an 'identity dilemma.' For the Nonhuman Animal rights movement, it appears likely that it could swell its ranks should it actively employ atheist claims-making or solicit areligious demographics. In doing so, however, it would also risk alienating the wider public given the widespread distrust of atheists. With the acceptance of both Nonhuman Animal rights and veganism already tenuous, the movement adopting an atheist identity would risk incurring what feminist Frances Beal (1969) might refer to as 'double jeopardy'.

The movement's hesitancy to redirect resources from religious campaigns may also relate to the well-known role that religiosity played in the Civil Rights Movement, the social protest movement that the Nonhuman Animal rights movement perhaps most actively seeks to emulate. The organisations spearheading such movements are known to be isomorphic in structure as well as strategy (DiMaggio and Powell 1983). Characteristically risk-averse, they are more likely to rely on tried and tested approaches. Thus, while there is little evidence of movements appealing to atheist demographics to advance their 
agendas, there are numerous examples of movements successfully deploying religiosity (Harris 2001).

\section{METHODS}

To outline the relationship between atheism and veganism, I revisited the results of an online survey on veganism and political identity that I had previously designed with Qualtrics and distributed in March 2017 via vegan Facebook groups and animal studies mailing lists. Only American citizens and self-identified vegans were invited to participate. Participants were asked to respond to approximately fifty questions measuring basic demographic information, political attitudes and opinions relating to their knowledge of and comfort with diversity within the Nonhuman Animal rights movement and in relation to American society. This survey was part of a larger project measuring diversity in the American vegan movement, meaning that no additional questions regarding the relationship between religion and veganism were asked of participants. This constituted a severe limitation because focused qualitative questioning with regard to participants' understanding of how their religiosity informs their veganism would have provided the most fruitful information.

\section{RESULTS}

Table 1. Frequencies

\begin{tabular}{lrr}
\hline Religion & Frequency & Per cent \\
\hline Atheist & 157 & $54.7 \%$ \\
Agnostic & 51 & $17.8 \%$ \\
Christian & 24 & $8.4 \%$ \\
Jewish & 19 & $6.6 \%$ \\
Muslim & 2 & $.7 \%$ \\
Other & 34 & $11.8 \%$ \\
\hline Total & 287 & $100.0 \%$ \\
\hline
\end{tabular}

Of the 364 people who responded to the invitation, only 287 respondents qualified to participate and completed the online survey. The majority of respondents stated that they were either atheist (55\%) or agnostic (18\%) (see Table 1). Forty one per cent of all respondents identified as female, $11 \%$ identified as male and $2 \%$ identified as non-binary. The remainder did not report their gender. Most men (72.7\%), women (71.2\%) and non-binary respondents $(83.3 \%)$ identified as atheist or agnostic. Most of those who did not report their gender $(73.1 \%)$ were also atheist or agnostic. The sample demonstrated considerable diversity in sexual orientation, with $65 \%$ identifying as heterosexual, 
$6.9 \%$ identifying as homosexual, $13.2 \%$ identifying as bisexual and $14 \%$ identifying as queer. The majority of homosexual (80\%), bisexual (65.8\%) and queer $(66.7 \%)$ respondents identified as atheist or agnostic.

While most respondents identified as white (78.7\%), $2.4 \%$ identified as Black, $4.8 \%$ Latinx, $5.9 \%$ Asian, $5.2 \%$ mixed race and $1 \%$ Native American (1.7\% did not respond). Atheists and agnostics were also in the majority across all racial categories except Native American (two of the three native respondents indicated that they were religious). Otherwise, $76.5 \%$ of white participants, $57.1 \%$ of Black, $57.1 \%$ of Latinx, $52.9 \%$ of Asian, $60 \%$ of mixed-race persons and $80 \%$ of those who chose not to respond identified as either atheist or agnostic.

Most participants became vegan out of concern for other animals, but a Pearson Chi-Square indicates a significant relationship between religiosity and reasons for adopting veganism at 19.498, with a significance of 0.034 (Table 2). The majority of atheists $(88.5 \%)$ adopted vegan lifestyles out of care for other animals, compared to $76.5 \%$ of agnostics, $79.2 \%$ of Christians, 68.4 $\%$ of Jews and $70.6 \%$ of other religions (100\% of Muslims became vegan for other animals, but only two participants identified as Muslim). Political identification was also correlated with spirituality, with a Pearson Chi-Square of 22.380 and a p value of 0.013 (Table 3). Atheists identified as Democrat at approximately the same rate as their religious counterparts, but were more likely to be socialist, anarchist or undecided than non-atheists. They were less likely, however, to identify as unaffiliated, non-partisan or independent voters.

Table 2. Religiosity and vegan rationale

\begin{tabular}{lrrrrrrr}
\hline & Atheist & Agnostic & Christian & Jewish & Muslim & Other & \multicolumn{1}{c}{ Total } \\
\hline Ethics & 139 & 39 & 19 & 13 & 2 & 24 & 236 \\
& $88.5 \%$ & $76.5 \%$ & $79.2 \%$ & $68.4 \%$ & $100.0 \%$ & $70.6 \%$ & $82.2 \%$ \\
Health & 5 & 5 & 4 & 1 & 0 & 5 & 20 \\
& $3.2 \%$ & $9.8 \%$ & $16.7 \%$ & $5.3 \%$ & $0 \%$ & $14.7 \%$ & $7.0 \%$ \\
Environ- & 13 & 7 & 1 & 5 & 0 & 5 & 31 \\
ment & $8.3 \%$ & $13.7 \%$ & $4.2 \%$ & $26.3 \%$ & $0 \%$ & $14.7 \%$ & $10.8 \%$ \\
\hline \multicolumn{2}{r}{} & & & Value & Df & Asymp. Sig. (2-sided) \\
\hline Pearson Chi-Square & & & $19.498 \mathrm{a}$ & 10 & 0.034 \\
Likelihood Ratio & & 18.102 & 10 & 0.053 \\
Linear-by-Linear Association & & 5.551 & 1 & 0.018 \\
N of Valid Cases & & & 287 & & \\
\hline
\end{tabular}

10 cells $(55.6 \%)$ have expected count less than 5 . The minimum expected count is 0.14 . 


\section{COREY LEE WRENN}

Table 3. Political identification of atheist and religious vegans

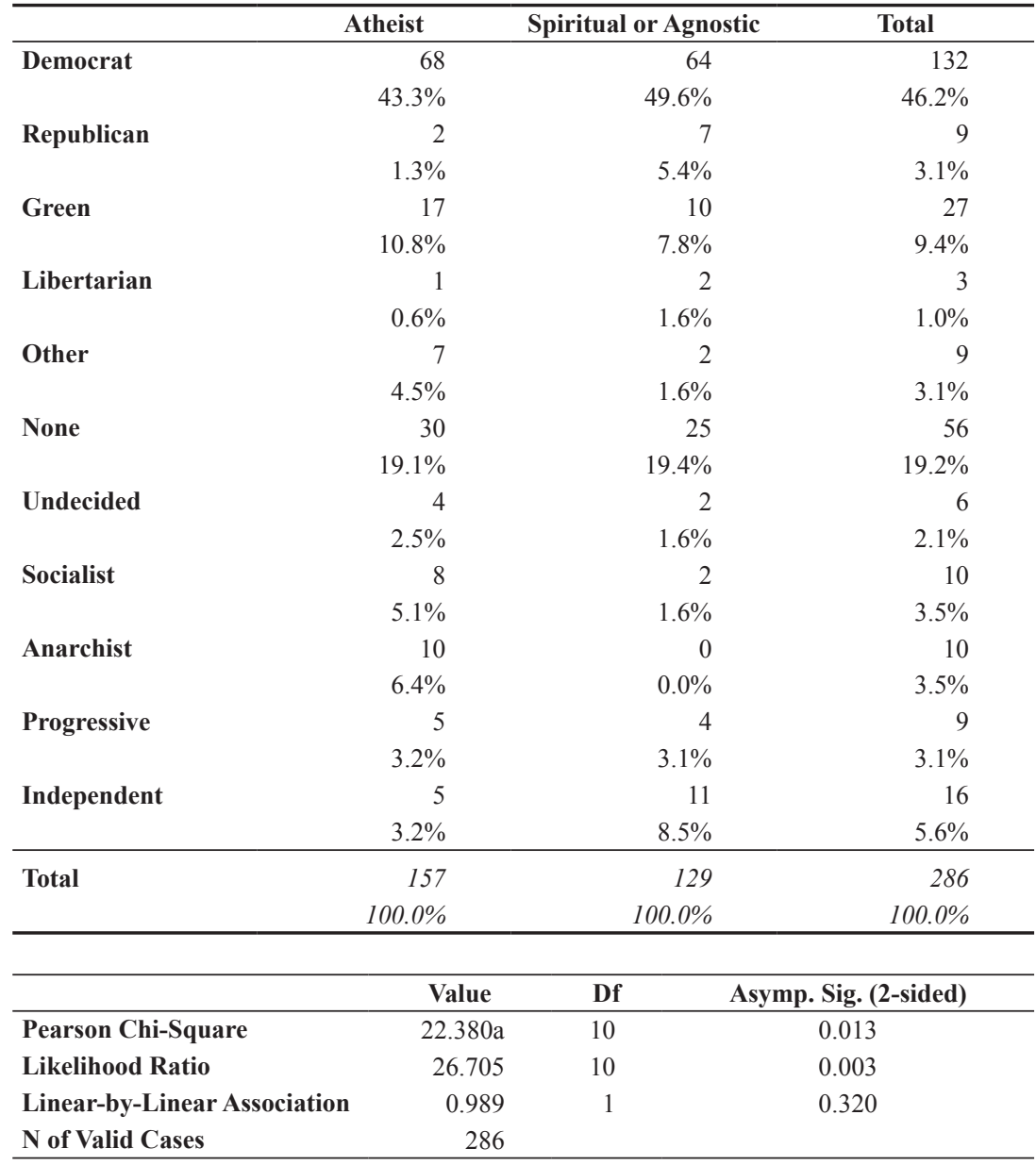

12 cells $(54.5 \%)$ have expected count less than 5 . The minimum expected count is 1.35 .

Atheists and agnostics were not significantly more likely to be involved with other social movements than religious participants. An independent t-test found a t score of 0.337 with a $p$ value of 0.737 for atheists and involvement (Table 4 ), and a t score of -0.809 with a value of 0.419 for both atheists and agnostics (Table 5). An independent t-test did find a significant relationship between religiosity and support for putting 'nonhumans first' over competing human justice concerns, with a t score of -2.591 and a p value of 0.010 (Table $6)$. The Pearson Chi-Square value was low here at 6.604 , but it was significant at 0.037 . The belief in putting nonhumans first is not simply a measure of movement commitment, but is associated with intersectional failure and sometimes 
ATHEISM IN THE AMERICAN ANIMAL RIGHTS MOVEMENT

Table 4. Atheism and involvement with other movements: Independent samples test

\begin{tabular}{|c|c|c|c|c|c|c|c|c|c|}
\hline & & & & $\mathrm{I}$ & & ean & td. Deviat & ion & Std. Error Mean \\
\hline Invo & & Atheis & & 15 & & 140 & 3.000 & & 0.23943 \\
\hline $\begin{array}{l}\text { with } \\
\text { Mov }\end{array}$ & $\begin{array}{l}\text { Other } \\
\text { ments }\end{array}$ & $\begin{array}{l}\text { Spiritu } \\
\text { Agnos }\end{array}$ & $\begin{array}{l}\text { al or } \\
\text { tic }\end{array}$ & 13 & & 923 & 3.10 & & 0.27224 \\
\hline & $\begin{array}{r}\text { Leven } \\
\text { Equality }\end{array}$ & $\begin{array}{l}\text { 's Test } \\
\text { of Vari }\end{array}$ & $\begin{array}{l}\text { for } \\
\text { ances }\end{array}$ & & & t-test fo & or Equality & of Mean & \\
\hline & & $\mathbf{F}$ & Sig. & $\mathbf{T}$ & df & $\begin{array}{c}\text { Sig. } \\
\text { (2-tailed) }\end{array}$ & $\begin{array}{c}\text { Mean } \\
\text { Differ- } \\
\text { ence }\end{array}$ & $\begin{array}{l}\text { Std. } \\
\text { Error } \\
\text { Differ- }\end{array}$ & $\begin{array}{l}\text { 95\% Confidence } \\
\text { Interval of the } \\
\text { Difference }\end{array}$ \\
\hline & & & & & & & & ence & Lower Upper \\
\hline 起 & $\begin{array}{l}\text { Equal } \\
\text { variances } \\
\text { assumed }\end{array}$ & 0.003 & 0.955 & 0.337 & 285 & 0.737 & 0.12171 & 0.36139 & -0.589620 .83303 \\
\hline 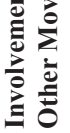 & $\begin{array}{l}\text { Equal } \\
\text { variances } \\
\text { not } \\
\text { assumed }\end{array}$ & & & 0.336 & 271.447 & 0.737 & 0.12171 & 0.36255 & 0.592060 .83547 \\
\hline
\end{tabular}

Table 5. Atheism and agnosticism and involvement with other movements:

Independent samples test

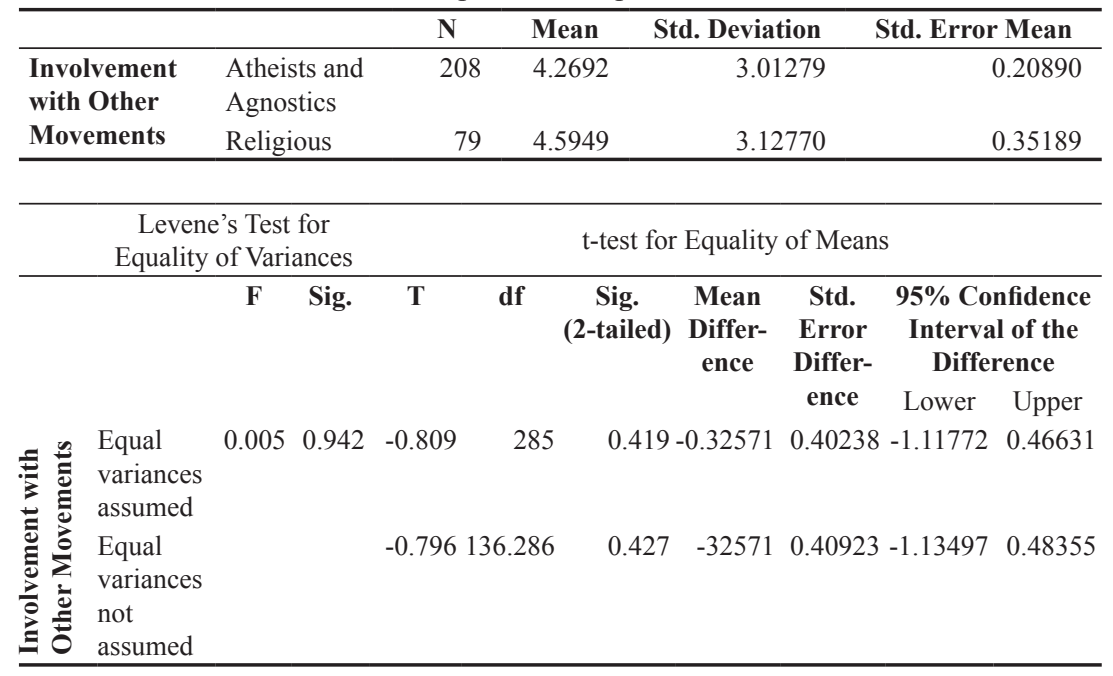

misanthropy within the Nonhuman Animal rights movement. Atheists and agnostics register a more encompassing ethic of compassion. Forty three per cent of atheists and agnostics disagree that nonhumans should be put first compared to just $27 \%$ of religious people (Table 7). Only one in four atheists and agnostics supported this statement, compared to $39 \%$ of religious respondents. 


\section{COREY LEE WRENN}

Atheists and agnostics were also no more or less likely to support coalition building with other social justice movements, with a low Pearson Chi-Square value of just 0.309 and a p value of 0.857 (Table 8).

Table 6. Religiosity and support for 'nonhumans first': Independent samples test

\begin{tabular}{llccrr}
\hline & & N & Mean & Std. Deviation & Std. Error Mean \\
\hline $\begin{array}{l}\text { Agreement } \\
\text { with } \\
\begin{array}{l}\text { 'Nonhumans } \\
\text { First' }\end{array}\end{array}$ & $\begin{array}{l}\text { Atheists or } \\
\text { Agnostic }\end{array}$ & 184 & 4.2880 & 3.25235 & 0.23977 \\
\hline
\end{tabular}

\begin{tabular}{|c|c|c|c|c|c|c|c|c|c|c|}
\hline \multirow{5}{*}{ 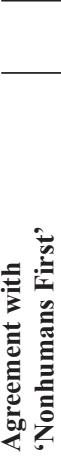 } & \multicolumn{3}{|c|}{$\begin{array}{c}\text { Levene's Test for } \\
\text { Equality of Variances }\end{array}$} & \multicolumn{7}{|c|}{ t-test for Equality of Means } \\
\hline & \multirow{2}{*}{\multicolumn{2}{|c|}{$\mathbf{F}$}} & \multirow[t]{2}{*}{ Sig. } & \multirow[t]{2}{*}{$\mathbf{T}$} & \multirow[t]{2}{*}{ df } & \multirow{2}{*}{\multicolumn{2}{|c|}{$\begin{array}{cc}\text { Sig. } & \text { Mean } \\
\text { (2-tailed) } & \begin{array}{c}\text { Differ- } \\
\text { ence }\end{array}\end{array}$}} & \multirow{2}{*}{$\begin{array}{c}\text { Std. } \\
\text { Error } \\
\text { Differ- } \\
\text { ence }\end{array}$} & \multicolumn{2}{|c|}{$\begin{array}{l}\text { 95\% Confidence } \\
\text { Interval of the } \\
\text { Difference }\end{array}$} \\
\hline & & & & & & & & & Lower & Upper \\
\hline & $\begin{array}{l}\text { Equal } \\
\text { variances } \\
\text { assumed }\end{array}$ & 0.079 & 0.779 & -2.591 & 252 & $0.010-$ & -1.19767 & 0.46231 & -2.10816 & -0.28718 \\
\hline & $\begin{array}{l}\text { Equal } \\
\text { variances } \\
\text { not } \\
\text { assumed }\end{array}$ & & & -2.541 & 20.061 & $0.012-$ & -1.19767 & 0.47136 & -2.13094 & -0.26411 \\
\hline
\end{tabular}

Table 7. Support for 'nonhumans first' by religiosity

\begin{tabular}{|c|c|c|c|}
\hline & Atheist or Agnostic & Religious & Total \\
\hline \multirow[t]{2}{*}{ Do Not Support } & 79 & 19 & 98 \\
\hline & $42.9 \%$ & $27.1 \%$ & $38.6 \%$ \\
\hline \multirow[t]{2}{*}{ Neutral } & 59 & 24 & 83 \\
\hline & $32.1 \%$ & $34.3 \%$ & $32.7 \%$ \\
\hline \multirow[t]{2}{*}{ Support } & 46 & 27 & 73 \\
\hline & $25.0 \%$ & $38.6 \%$ & $28.7 \%$ \\
\hline \multirow[t]{3}{*}{ Total } & 184 & 70 & 254 \\
\hline & $100.0 \%$ & $100.0 \%$ & $100.0 \%$ \\
\hline & Value & \multicolumn{2}{|r|}{ Asymp. Sig. (2-sided) } \\
\hline Pearson Chi-Square & $6.604 a$ & \multicolumn{2}{|r|}{0.037} \\
\hline Likelihood Ratio & 6.660 & \multicolumn{2}{|r|}{0.036} \\
\hline $\begin{array}{l}\text { Linear-by-Linear } \\
\text { Association }\end{array}$ & 6.563 & \multicolumn{2}{|r|}{0.010} \\
\hline $\mathbf{N}$ of Valid Cases & 254 & & \\
\hline
\end{tabular}

0 cells $(.0 \%)$ have expected count less than 5 . The minimum expected count is 20.12 . 


\section{ATHEISM IN THE AMERICAN ANIMAL RIGHTS MOVEMENT}

Table 8. Support for involvement with other movements by religiosity

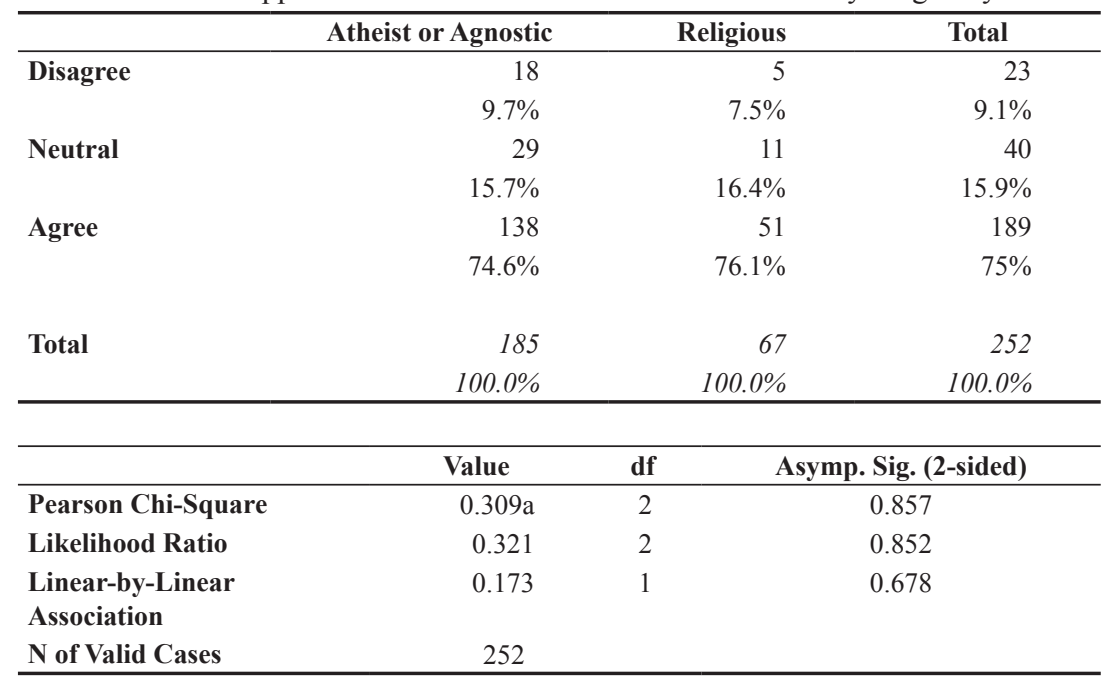

0 cells $(.0 \%)$ have expected count less than 5 . The minimum expected count is 6.12 .

Lastly, there was not a strong relationship between religiosity and feeling comfortable or welcomed in the movement (Table 9). The Pearson Chi-Square value was low at 1.581 and the $\mathrm{p}$ value was not significant at 0.454 .

Table 9: Degree to which vegans feel welcome according to religiosity

\begin{tabular}{|c|c|c|c|c|}
\hline & Atheist or Agnostic & & Religious & Total \\
\hline \multirow[t]{2}{*}{ Uncomfortable } & 40 & & 18 & 58 \\
\hline & $21.6 \%$ & & $25.4 \%$ & $22.7 \%$ \\
\hline \multirow[t]{2}{*}{ Somewhat Comfortable } & 48 & & 22 & 70 \\
\hline & $25.9 \%$ & & $31.0 \%$ & $27.3 \%$ \\
\hline \multirow[t]{2}{*}{ Comfortable } & 97 & & 31 & 128 \\
\hline & $52.4 \%$ & & $43.7 \%$ & $50.0 \%$ \\
\hline \multirow[t]{3}{*}{ Total } & 185 & & 71 & 256 \\
\hline & $100.0 \%$ & & $100.0 \%$ & $100.0 \%$ \\
\hline & Value & df & \multicolumn{2}{|c|}{ Asymp. Sig. (2-sided) } \\
\hline Pearson Chi-Square & $1.581 \mathrm{a}$ & 2 & \multicolumn{2}{|c|}{0.454} \\
\hline Likelihood Ratio & 1.584 & 2 & \multicolumn{2}{|c|}{0.453} \\
\hline Linear-by-Linear Association & 1.225 & 1 & \multicolumn{2}{|c|}{0.268} \\
\hline $\mathrm{N}$ of Valid Cases & 256 & & & \\
\hline
\end{tabular}

0 cells $(.0 \%)$ have expected count less than 5 . The minimum expected count is 16.09 . 


\section{COREY LEE WRENN}

\section{DISCUSSION}

These results demonstrate that atheists and agnostics are a leading demographic in the vegan movement, alongside whites and women. This is consistent with previous studies that measured religiosity in the Nonhuman Animal rights movement (Gabriel et al. 2012; Galvin and Herzog 1992; Guither 1998; The Humane League 2014). Other research finds that women comprise eighty per cent of Nonhuman Animal rights activists (Gaarder 2011), and that women are much more likely to be vegan (Wardle et al. 2004; Wright 2015). Nearly half of the respondents in this study declined to report their gender but, of those who did, women dominated. However, gender and race have already been examined as dominant variables in the American vegan movement (Kymlicka and Donaldson 2014; Gaarder 2011), while atheism, despite its comparable relevance, remains relatively invisible in Nonhuman Animal rights mobilisation literature.

In addition to making up the majority in vegan communities, atheists constitute a unique group in their motivational profile. Atheists are more likely to become vegan out of concern for Nonhuman Animal ethics, and this holds consistent with psychological research that finds them more analytically minded (Pennycook et al. 2016), but also particularly motivated by compassion (Saslow et al. 2013). Furthermore, atheists and agnostics are about as likely to identify as Democrat as religious citizens, and more likely to identify as socialist and anarchist. Another extension of these correlations is the vegan atheist disagreement with the concept of putting Nonhuman Animals first. This position has been criticised by movement scholars and leaders on account of its tendency to override and dismiss sexism, racism and other systems of inequality that not only concern neighbouring social justice movements, but also vegan activists who themselves experience structural inequality and discrimination (Kymlicka and Donaldson 2014; Gaarder 2011). Indeed, the movement's failure to effectively build coalitions has been a hindrance to its success and, while the atheist demographic's lower support for 'nonhumans first' suggests a greater interest in this coalition building, atheist respondents in this study were no more likely than non-atheists to be involved with support greater cooperation with other movements.

Although women and people of colour have indicated that they often feel unwelcome or unsupported in the Nonhuman Animal rights movement (Wrenn 2017a; Gorski et al. 2018), this problem did not extend to participating atheists, despite the widespread stigmatisation of this group in American society (Edgell et al. 2006, 2016; Hammer et al. 2012). The reasons for the relative comfort of atheists within the Nonhuman Animal rights movement is unclear, although it could be that atheists have little reason to experience overt discrimination if they are not openly identified as atheist. Given that atheism is 
so rarely discussed and researched in the vegan context, there is little reason to presume that atheists are 'out' or open about their religious affiliations.

\section{CONCLUSION}

This study has sought to quantify the existence of atheists in the American vegan movement and qualified, to some extent, their demographic profile. Results discussed herein derive from a larger study focusing on attitudes towards diversity within this growing movement. As such, these findings provide an important starting point, but additional qualitative interviewing would be required for sufficient examination to take place. It would also be useful to investigate leadership structures of nonprofit organisations and other campaign groups to ascertain the level of awareness of atheist ranks and any rationale for avoiding atheist frameworks.

This survey can only speak to the basic characteristics of this demographic, although it has also not measured the reasons for atheist invisibility, which could very well relate to the wider societal stigmatisation of the areligious. Historically, Nonhuman Animal rights campaigns appealed to religious hegemony to lend credence to their claims. Religious groups also mobilised vegetarianism and kindness to other animals as evidence of their devotion and spiritual purity. These cultural frames leave little room for the recognition of atheists by vegan or nonhuman rights advocates. The Nonhuman Animal rights movement's contemporary engagement with secular claims-making most likely accounts for the atheist majority it exhibits today, yet its continuing silence on atheist thought must be strategic. In their research of anti-atheist discrimination, Edgell et al. $(2006,2016)$ find that religiosity is central to group membership and acceptance in American culture. Social protest movements may therefore be hesitant to destroy their chances at societal acceptance by appearing to reject their alignment with such mainstream cultural values.

A further avenue of enquiry concerns the potential impact this avoidance may have on the wellbeing of the atheist rank-and-file. A major element of anti-atheist discrimination is the pressure for atheists to 'pass' as religious or at least open to religious beliefs. This phenomenon disavows the atheist identity and thus contributes to the psychological distress of atheist individuals (Brewster et al. 2016). If the Nonhuman Animal rights movement is actively discouraging atheists from expressing their areligious identity - or worse, if it is pressuring atheist activists to embrace a false religious identity in their interactions with movement audiences - this would itself constitute a violation of civil rights. My study does not provide evidence of this possibility, but the movement's failure to openly embrace atheism suggests to me that there is potential for this kind of behaviour. 


\section{COREY LEE WRENN}

The Nonhuman Animal rights movement already has a negative reputation for its treatment of fat persons (Wrenn 2017b), disabled persons (Taylor 2017), women or those who identify as women (Gaarder 2011) and people of colour (Kymlicka and Donaldson 2014), such that sustaining an anti-atheist bias in its framework is not likely to improve its public relations, at least within social justice spaces. Reaching out to the atheist community and encouraging atheist vegans to be open about their identity could be one step toward improving movement inclusivity. As evidenced by research on the psychological development of homosexual persons (Savin-Williams 2008) and mentally ill persons (Corrigan et al. 2010), being 'out' is linked with improved self-esteem and quality of life. In the atheist community in the US, the process of 'coming out' allows for an element of agency over one's place in society, particularly for those who consider themselves activists interested in recruiting new atheists (Cloud 2017). As with other stigmatised groups, this 'coming out' fosters empowerment, a sense of liberation and improved confidence (Smith 2011). However, research into the 'coming out' processes for homosexuality, mental illness and atheism also acknowledges certain costs and risks associated with the strategy. Understandably, many American atheists actively conceal their identity as a means of stigma management, given the fact that open identification appears to invite more discrimination.

At the same time, the atheist movement has consistently demonstrated hostility towards veganism and anti-speciesism, despite the fact that atheists are one of the dominant demographics in the Nonhuman Animal rights movement (Wrenn 2016). What this indicates is that atheists predominate as vegans and anti-speciesists even though the atheist movement is, in general, hostile to these positions and the Nonhuman Animal rights movement has failed to canvas the atheist community. If the movement were to actively solicit atheists, then, there is reason to believe that this campaign would be hugely successful given that so many atheists are already mobilised in spite of institutional barriers. The atheist movement's interest in scepticism may also be conducive to the growth and success of both veganism and nonhuman rights campaigns. Atheists would likely respond positively to the vegan movement's commitment to challenging unsubstantiated claims, legislation and corporations that protect the use and consumption of Nonhuman Animals, as well as the murky science that obscures the role of speciesism in climate change. Within the atheist movement, there is also a growing interest in intersectionally oriented social justice (Christina 2012), with atheism positioned as an important cornerstone in challenging race, class and gender discrimination. Given the centrality of atheism to the vegan consumer-base, this emergent framework could surely be persuaded to include species discrimination as well as intersectional inequality in its social justice and advocacy work. 


\section{ATHEISM IN THE AMERICAN ANIMAL RIGHTS MOVEMENT}

\section{REFERENCES}

Beal, F. 1969. Black Women's Manifesto; Double Jeopardy: To Be Black and Female. Online at: http://www.hartford-hwp.com/archives/45a/196.html (accessed 18 April 2019).

Beers, D. 2006. For the Prevention of Cruelty. Athens, OH: Ohio University Press. Crossref

Boddice, R. 2008. A History of Attitudes and Behaviors Toward Animals. Lewiston, NY: The Edwin Mellen Press.

Bresnahan, M., J. Zhuang and X. Zhu. 2016. 'Why is the vegan line in the dining hall always the shortest? Understanding vegan stigma'. Stigma and Health 1(1): 3-15. Crossref

Brewster, M., J. Hammer, J. Sawyer, E. Eklund and J. Palamar. 2016. 'Perceived experiences of atheist discrimination: Instrument development and evaluation'. Journal of Counseling Psychology 63(5): 557-570. Crossref

Cloud, D. 2017. 'Rewriting a discursive practice: Atheist adaptation of coming out discourse'. Written Communication 34(2): 165-188. Crossref

Cole, M. and K. Morgan. 2011. 'Vegaphobia: Derogatory discourses of veganism and the reproduction of speciesism in UK national newspapers'. The British Journal of Sociology 62(1): 134-153. Crossref

Corrigan, P., S. Morris, J. Larson, J. Rafacz, A. Wassel, P. Michaels, S. Wilkniss, K. Batia and N. Rüsch. 2010. 'Self-stigma and coming out about one's mental illness'. Journal of Community Psychology 38(3): 259-275. Crossref

Christina, G. 2012. Atheism Plus, and Some Thoughts on Divisiveness. The Orbit. Online at: https://the-orbit.net/greta/2012/08/30/atheism-plus-and-some-thoughtson-divisiveness/ (accessed 1 January 2018).

Davis, J. 2016. The Gospel of Kindness; Animal Welfare and the Making of Modern America. New York, NY: Oxford University Press. Crossref

Dhont, K. and G. Hodson. 2014. 'Why do right-wing adherents engage in more animal exploitation and meat consumption?' Personality and Individual Difference 64: 12-17. Crossref

DiMaggio, P. and W. Powell. 1983. 'The iron cage revisited: Institutional isomorphism and collective rationality in organizational fields'. American Sociological Review 48(2): 147-160. Crossref

Edgell, P., J. Gerteis and D. Hartmann. 2006. 'Atheists as 'other': Moral boundaries and cultural membership in American society'. American Sociological Review 71(2): 211-234. Crossref

Edgell, P., D. Hartmann, E. Stewart and J. Gerteis. 2016. 'Atheists and other cultural outsiders: Moral boundaries and the non-religious in the United States'. Social Forces 95(2): 607-638. Crossref

Ferguson, M. 1998. Animal Advocacy and Englishwomen, 1790-1900. Ann Arbor, MI: University of Michigan Press. Crossref

Fox, M. 1983. 'The question of atheism and communism in the animal welfare/rights movement'. International Journal for the Study of Animal Problems 4(3): 171-173. 


\section{COREY LEE WRENN}

Francis, R. 2010. Fruitlands: The Alcott Family and Their Search for Utopia. New Haven, CT: Yale University Press.

Freeman, C. 2014. Framing Farming. New York, NY: Rodopi.

Gaarder, E. 2011. Women and the Animal Rights Movement. Philadelphia, PA: Temple University Press.

Gabriel, K., B. Rutledge and C. Barkley. 2012. 'Attitudes on animal research predict acceptance of genetic modification technologies by university undergraduates'. Society \& Animals 20(4): 381-400. Crossref

Galvin, S. and H. Herzog. 1992. 'Ethical ideology, animal rights activism, and attitudes toward the treatment of animals'. Ethics and Behavior 2(3): 141-149. Crossref

Garner, R. 1998. Political Animals. Basingstoke and London: Palgrave Macmillan. Crossref

Goffman, E. 1963. Stigma. New York, NY: Simon and Schuster.

Gorski, P., S. Lopresti-Goodman and D. Rising. 2018. "Nobody's paying me to cry": The causes of activist burnout in United States animal rights activists'. Social Movement Studies 18(3): 364-380.

Greenebaum, J. 2012. 'Managing impressions: 'Face-saving' strategies of vegetarians and vegans'. Humanity \& Society 36(4): 309-325. Crossref

Greenebaum, J. 2016. 'Questioning the concept of vegan privilege'. Humanity \& Society 41(3): 355-372.

Guither, H. 1998. Animal Rights: History and Scope of a Radical Social Movement. Carbondale, IL: Southern Illinois University Press.

Halteman, M. 2018. 'We are all Noah: Tom Regan's olive branch to religious animal ethics'. Between the Species 21: 152-177.

Hammer, J., R. Cragun, K. Hwang and J. Smith. 2012. 'Forms, Frequency, and correlates of perceived anti-atheist discrimination'. Secularism \& Nonreligion 1: 43-67. Crossref

Harris, F. 2001. 'Religious resources in an oppositional civic culture'. In J. Mansbridge and A. Morris (eds), Oppositional Consciousness, pp. 38-64. Chicago, IL: The University of Chicago Press.

Holroyd, M. 1997. Bernard Shaw: The One-Volume Definitive Edition. London: Chatto \& Windus.

The Humane League. 2014. Diet Change and Demographic Characteristics of Vegans, Vegetarians, Semi-Vegetarians, and Omnivores. Philadelphia, PA: The Humane League.

Iacobbo, K. and M. Iacobbo. 2006. Vegetarians and Vegans in America Today. Westport, CT: Praeger.

Jamison, W. and W. Lunch. 1992. 'Rights of animals, perceptions of science, and political activism: Profile of American animal rights activists'. Science, Technology and Human Values 17(4): 438-458. Crossref

James, W. 1948. 'Veganism and science - and a warning'. The Vegan 4(1): 6-7.

Jarvis, G. 2009. 'The road not taken: Humanitarian reform and the origins of animal rights in Britain and the United States, 1883-1919'. Ph.D. dissertation. University of Iowa. 


\section{ATHEISM IN THE AMERICAN ANIMAL RIGHTS MOVEMENT}

Jasper, J. and D. Nelkin. 1992. The Animal Rights Crusade. New York, NY: Free Press.

Kean, H. 1995. 'The "smooth cool men of science": The feminist and socialist response to vivisection'. History Workshop Journal 40(1): 16-38. Crossref

Kemmerer, L. 2012. Animals and World Religions. New York, NY: Oxford University Press.

Kymlicka, W. and S. Donaldson. 2014. 'Animal rights, multiculturalism, and the Left'. Journal of Social Philosophy 45(1): 116-135. Crossref

Li, C. 2012. 'An unnatural alliance? Political radicalism and the animal defence movement in late Victorian and Edwardian Britain'. EurMerica 42(1): 1-43.

Maurer, D. 2002. Vegetarianism: Movement or Moment? Philadelphia, PA: Temple University Press.

McDonald, B. 2000. “'Once you know something, you can't not know it': An empirical look at becoming vegan'. Society \& Animals 8(1): 1-23.

McGarry, A. and J. Jasper. 2015. 'Introduction: The identity dilemma, social movements, and contested identity'. In J. Jasper and A. McGarry (eds), Identity Dilemma, pp. 1-17. Philadelphia, PA: Temple University Press.

Maehle, A. 2012. 'Cruelty and kindness to the 'brute creation': Stability and change in the ethics of the man-animal relationship, 1600-1850'. In A. Manning and J. Serpell (eds), Animals and Human Society, pp. 81-105. New York, NY: Routledge.

Minson, J. and B. Monin. 2011. 'Do-gooder derogation: Disparaging morally-motivated minorities to defuse anticipated reproach'. Social Psychological and Personality Science 3(2): 200-207. Crossref

Monteiro, C. 2012. The Effects of Graphic Images on Attitudes towards Animal Rights. FARM. Online at: http://www.blog.farmusa.org/the-effects-of-graphic-images-onattitudes-towards-animal-right (accessed 17 October 2012).

Munro, L. 2005. Confronting Cruelty. Leiden, Netherlands: Brill Academic Publishers.

Murphy, M. 2015. Compassionate Stranger: Asenath Nicholson and the Great Irish Famine. Syracuse, NY: Syracuse University Press.

Nibert, D. 2013. Animal Oppression and Human Violence. New York, NY: Columbia University Press.

Peek, C., M. Konty and T. Frazier. 1997. 'Religion and ideological support for social movements: The case of animal rights'. Journal for the Scientific Study of Religion 36(3): 429-39. Crossref

Pennycook, G., R. Ross, D. Koehler and J. Fugelsang. 2016. 'Atheists and agnostics are more reflective then religious believers: Four empirical studies and a metaanalysis'. PLOS One. 11(4): e 0153039. Crossref

Preece, R. 2006. Brute Souls, Happy Beasts, and Evolution. Vancouver, BC: The University of British Columbia Press.

Regan, T. 1983. The Case for Animal Rights. Berkeley, CA: University of California Press.

Ritter, R. and J. Preston. 2011. 'Gross gods and icky atheism: Disgust responses to rejected religious beliefs'. Journal of Experimental Social Psychology 47(6): 12251230. Crossref

Ritvo, H. 1989. The Animal Estate. Cambridge, MA: Harvard University Press. 


\section{COREY LEE WRENN}

Rollin, B. 2009. 'An Ethicist's commentary on religion and animal ethics'. The Canadian Veterinary Journal 50(4): 346-349.

Ryder, R. 1989. Animal Revolution: Changing Attitudes Toward Speciesism. Oxford: Blackwell Publishers.

Saslow, L., R. Willer, M. Feinberg, P. Piff, K. Clark, D. Keltner and S. Saturn. 2013. 'My brother's keeper? Compassion predicts generosity more among religious individuals'. Social Psychology and Personality Science 4(1): 31-38. Crossref

Savin-Williams, R. 2008. 'Coming out to parents and self-esteem among gay and lesbian youths'. Journal of Homosexuality 18(1-2): 1-35. Crossref

Shapiro, K. 2018. 'A faith built on awe: Reframing atheism'. Worldviews 22(3): 199215. Crossref

Shprintzen, A. 2015. The Vegetarian Crusade: The Rise of an American Reform Movement, 1817-1921. Chapel Hill, NC: The University of North Carolina Press.

Singer, P. and J. Mason. 2006. The Ethics of What We Eat. Emmaus, PA: Rodale.

Singer, P. and M. Hauser. 2017. 'Godless morality'. In P. Singer (ed.), Ethics in the Real World, pp. 15-18. Princeton, NJ: Princeton University Press.

Singer, P. (1975) 2002. Animal Liberation. New York, NY: Ecco Press.

Singer, P. 1979. Practical Ethics. New York, NY: Cambridge University Press.

Smith, J. 2011. 'Becoming an atheist in America: Constructing identity and meaning from the rejection of theism'. Sociology of Religion 72(2): 215-237. Crossref

Socha, K. 2014. Animal Liberation and Atheism. Minneapolis, MN: Free Thought House.

Stallwood, K. 2014. GROWL. New York, NY. Lantern Books.

Taylor, S. 2017. Beasts of Burden: Animal and Disability Liberation. New York, NY: New Press.

Turner, R. 2019. 'Veganism: ethics in everyday life'. American Journal of Cultural Sociology 7(1):54-78. Crossref

Wardle, J., A. Haase, A. Steptoe, M. Nillapun, K. Jonwutiewes and F. Bellisie. 2004. 'Gender differences in food choice. The contribution of health beliefs and dieting'. Annals of Behavioral Medicine 27(2): 107-116. Crossref

Williamson, D. and G. Yancey. 2013. There is No God: Atheists in America. Lanham, MD: Rowman and Littlefield Publishing Group, Inc.

Wrenn, C. 2016. A Rational Approach to Animal Rights. New York, NY: Palgrave.

Wrenn, C. 2017a. 'Trump veganism: A political survey of american vegans in the era of identity politics'. Societies 7(4): 32. Crossref

Wrenn, C. 2017b. 'Fat vegan politics: A survey of fat vegan activists' online experiences with social movement sizeism'. Fat Studies 6(1): 90-102. Crossref

Wrenn, C. 2018. 'Free-riders in the non-profit industrial complex: The problem of flexitarianism'. Society \& Animals 1(aop): 1-25. Online at: https://brill.com/view/ journals/soan/aop/article-10.1163-15685306-12341544.xml (accessed 17 April 2019).

Wrenn, C. 2019. 'From seed to fruition: A political history of The Vegan Society, 19442017'. Food and Foodways 27(3). In press. 
Wrenn, C. 2020. Piecemeal Protest: Animal Rights in the Age of Nonprofits. Ann Arbor, MI: University of Michigan Press. In press.

Wright, J. and R. Nichols. 2014. 'The social cost of atheism: How perceived religiosity influences moral appraisal'. Journal of Cognition and Culture 14(1-2): 93-115. Crossref

Wright, L. 2015. The Vegan Studies Project: Food, Animals, and Gender in the Age of Terror. Athens, GA: The University of Georgia Press. 
